\title{
Recommendations regarding Governments, Political Organizations, and Institutions
}

The Shoah was the most horrendous expression of Jew-hatred and shattered the illusions of Western culture. Nevertheless, eighty years after the November 1938 pogroms known as "Kristallnacht," antisemitism is reviving to a shocking extent, and most measures of governments to fight antisemitism seem to have had only a limited effect.

The year 2018 marks not only the eightieth anniversary of Kristallnacht but also the seventieth anniversary of the Universal Declaration of Human Rights. The anniversaries of 2018 thus give us both reason to mourn and to celebrate.

Fighting antisemitism should be in the self-interest of all because the violence and hatred of antisemitism often targets Jews first but never stops at victimizing Jews only. History teaches us that the intolerance and violence of antisemites can often be a precursor to the targeting of other minorities as well.

While antisemitism appears on its surface to be a phenomenon uniquely directed against Jews, it has broader significance. The nature of antisemitic groups and their theories is such that ultimately it leads to hatred directed against those parts of society that reject antisemitism. It therefore constitutes a major danger not only to Jews but to society at large. Thus all governments and governmental agencies of all states have a special responsibility to do their utmost to repress and eradicate antisemitism.

To confront antisemitism and to render it impotent, antisemitism must be actively challenged by political decision makers who have the power to affect and impact our world. While civil society has an important role to play, the fight against antisemitism cannot be left only in its hands. The task of eradicating antisemitism, as well as other forms of bigotry and hatred, must be a partnership of civil society and government. History shows that whenever governments supported and protected their Jewish citizens, Jewish minorities thrived and proved beneficial for the societies in which they lived. Whenever governments did not accept the responsibility to protect their Jewish citizens, persecution and murder ensued, and state economies and cultures suffered from the loss of some of their most important contributors.

The following is an attempt to assess the problems facing contemporary governments and their agencies as well as intergovernmental agencies regarding the recent manifestations of antisemitism, and to suggest a line of recommendations for possible action to combat them. Three introductory remarks are in order. 
1. Although to some extent we address government here as a whole, i.e., as the institution whose responsibility it is to protect all citizens, we are aware that separation of powers is one of the most important characteristics of democratic governments. Several policy recommendations concern all three branches of government, legislative, judiciary, and executive, for example, if antisemites can be employed by any branch of government. We are also aware that not all democratic systems practice the trias politicas, i.e., the separation of powers into three branches, but have chosen other forms of the separation of powers.

2. When taking a look at the contemporary political arena, it becomes quite clear that recommendations may mainly be offered to democratic countries: their public life includes debates, venues for a variety of opinions, and above all, responsibility of the state towards all its citizens-majority and minorities alike. On the other hand, it is precisely this democratic variety of opinions that opens the door for all hues of political ideologies to be heard, liberal ones alongside xenophobic and segregating ones. The UK Labour party under Jeremy Corbyn's leadership is a striking example of fierce debates and of antisemitic statements and connotations expressed in the public sphere. Governments and regimes in non-democratic or anti-liberal countries exploit antisemitism and other prejudices for their political goals, both domestic and external. An example is the use of antisemitic attacks against the Jewish-Hungarian businessman George Soros in his home country and elsewhere.

3. As a result of the recent waves of immigration of refugees and seekers of better economic conditions, the political map in Europe as well as in the U.S. has changed drastically in the last decade. The discourse about this issue has resulted in heated debates and a polarization of the political field. A debate on absorbing minorities almost always has an impact on the local Jewish communities who are still considered a minority. This is especially true when most of the newcomers are Muslims coming from countries where antisemitism is state policy and where Israel is viewed as an illegitimate state.

Consequently, governments and intergovernmental agencies, no matter of what political inclination, face a deepening conflict that has been commonly described as a "crisis of democracy," that has changed the responses of governments to specific issues, antisemitism included. Governments are facing a new reality in which terrorism is a serious threat. They are therefore constantly confronted with the possible connection between antisemitism and terrorism and the deployment of police, army and intelligence to protect the public, Jewish communities included. France is a case in point. In France, Jews and non- 
Jews have been killed together in terrorist attacks. Despite large budgets, for education and security, the number of violent antisemitic incidents in France increased in 2017. ${ }^{1}$

Despite this complicated political picture, to which more difficulties arise daily, governmental and intergovernmental agencies have enhanced their activities against antisemitism and have taken better steps for the protection of Jewish communities over the last 15 years. According to Mike Whine, a senior representative of the UK in pan-European bodies for many years,

it is no exaggeration that there has never been so much analysis of antisemitism and activity to combat it as there is today. States now recognize that antisemitic hate crime constitutes an abuse of basic freedoms and human rights, and that they are obliged to prosecute perpetrators. $^{2}$

How is it possible that despite these governmental efforts antisemitism is on the rise? The reports of the Kantor Center at Tel Aviv University on "Antisemitism

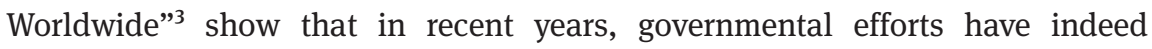
brought down the number of violent antisemitic incidents in some countries, yet other manifestations of antisemitism stayed on a high level and even increased, especially in those countries where major Jewish communities reside. ${ }^{4}$ Furthermore, verbal and visual manifestations of antisemitism, such as threats, harassments, insults, and other hateful expressions have all been severely on the rise in recent years. In addition, surveys show that large parts of the world's populations harbor antisemitic prejudices. ${ }^{5}$ Such attitudes have resulted in deep

1 Cf. Kantor Center for the Study of Contemporary European Jewry at Tel Aviv University, “Antisemitism Worldwide 2017 Report,” April 11, 2018, https://eurojewcong.wpengine.com/re sources/antisemitism-worldwide-2017-report/, 54-5.

2 M. Whine, "Can the European Agencies Combat Antisemitism Effectively?" Israel Journal of Foreign Affairs 11, no. 3 (2017): 371.

3 General analyses of antisemitism worldwide have been conducted and documented by the Kantor Center for the Study of Contemporary European Jewry at Tel Aviv University since 2009. The Annual Kantor Center Worldwide Reports on Antisemitism can be downloaded online via http://kantorcenter.tau.ac.il/general-analyses-antisemitism-worldwide (accessed October 8, 2018).

4 Kantor Center for the Study of Contemporary European Jewry and the Moshe Kantor Database for the Study of Antisemitism and Racism, General Analysis of Antisemitism Worldwide 2017, 5-17, http://kantorcenter.tau.ac.il/sites/default/files/Doch_full_2018_220418.pdf. Violent cases, which numbered worldwide 600-700 cases a year from 2007 to 2014, number since then $350-450$.

5 Due to differences in methodology, the results of the individual surveys differ from each other, but all point to a significant rise of antisemitic prejudice in the world's population. Examples for 
anxiety on the part of Jews who are alarmed by the hostile environment that surrounds them.

The discrepancy, between the governmental and intergovernmental efforts and the reality on the ground, is the reason that makes us dare suggest here a number of recommendations, that we hope will help to rectify the situation.

\section{Recommendations for Decision Makers and Influencers in all Three Branches of Government}

The recommendations below concern decision makers and influencers in all branches of government, at the national, regional, and local levels. As outlined in the executive sumary (see p. 13-17), we would like to recommend policies that concern, on the one hand, the short-term restraining of antisemitism and, on the other hand, its long-term eradication in a time span of several generations. Policies that concern the short-term suppression of antisemitism will lead to nothing if they are not accompanied by measures that are concerned with the long-term eradication of antisemitic contents from the world's religious and cultural memories. These must be replaced by positive contents about Judaism as well as by accurate depictions of the history of antisemitism from the perspective of the victims. All branches of government should do their outmost to achieve both aims.

One crucial recommendation is that all bodies and branches of government in all countries endorse and apply the Working Definition of Antisemitism (WDA) of the International Holocaust Remembrance Alliance (IHRA), that was officially adopted by the thirty-one member nations of IHRA and is accepted now by many governments and parliaments around the world. ${ }^{6}$ The full text of the definition

such surveys include the survey of the Anti-Defamation League, "ADL Global 100: An Index of Anti-Semitism” (http://global100.adl.org/, accessed October 21, 2018), the survey of the European Fundamental Rights Agency, "Antisemitism - Overview of Data Available in the European Union, 2005-2016” (http://fra.europa.eu/en/publication/2017/antisemitism-overview-2006 2016, accessed October 21, 2018), and some of the results of the survey of the PEW Research Center "Being Christian in Western Europe" (http://www.pewforum.org/wp-content/uploads/sites/7/ 2018/05/Being-Christian-in-Western-Europe-FOR-WEB1.pdf, accessed October 21, 2018).

6 Until July 2018, the Working Definition of Antisemitism has been adopted and endorsed by the United Kingdom (December 12, 2016), Israel (January 22, 2017), City of London (February 8, 2017), Austria (April 25, 2017), Scotland (April 27, 2017), Romania (May 25, 2017), Germany (September 20, 2017), Bulgaria (October 18, 2017), Lithuania (January 24, 2017), and Republic of Macedonia (March 6, 2018). Cf. "Working Definition of Antisemitism," International Holocaust 
can be found on p. 565-6 of the present volume. Its central statement is as follows:

Antisemitism is a certain perception of Jews, which may be expressed as hatred toward Jews. Rhetorical and physical manifestations of antisemitism are directed toward Jewish or non-Jewish individuals and/or their property, toward Jewish community institutions and religious facilities.

A statement by the office of the Prime Minister of the UK issued at the end of 2016 illustrates the importance to the WDA for governmental work, i.e., to

ensure that culprits will not be able to get away with being antisemitic because the term is ill defined, or because different organizations or bodies have different interpretations of it. ${ }^{7}$

The WDA is a guideline for understanding antisemitism, and a practical guide to identify incidents, to collect data and to support implementation of the legislation concerning antisemitism.

Based on the WDA, we recommend that governmental and political decision makers and influencers employ a five-step process in fighting antisemitism.

1. Assessment: Assessing the level of antisemitism in a country, a branch of government, a governmental agency, or a political party.

2. Comprehending the problem: Analyzing what motivates antisemitism and antisemitic discrimination in a country, a branch of government, a governmental agency, or a political party.

3. Awareness-raising: All inhabitants of a country and all members of a branch of government, a governmental agency, or a political party need to be sensitized towards the antisemitism in their country or organization.

4. Application of policies for combating antisemitism, at the national, PanEuropean, and international level.

5. Adjusting the general policies to combat antisemitism: The general policies suggested below need to be adjusted to the specific needs of each country, a branch of government, a governmental agency, or a political party.

Remembrance Alliance, July 19, 2018, https://www.holocaustremembrance.com/news-archive/ working-definition-antisemitism.

7 W. Williams, "Britain Has a New Official Definition of 'anti-Semitism,"” Business Insider Deutschland, December 13, 2016, https://www.businessinsider.de/britain-new-anti-semitismdefinition-2016-12? $r=U S \& I R=T$. 


\subsection{Assessment: Assessing the Level of Antisemitism in a Country, a Branch of Government, a Governmental Agency, or a Political Party}

The assessment of the level of antisemitism in a given country, branch of government, government agency or political party has three aspects. All three forms of assessing antisemitism should be carried out by professional and independent agencies, whether academic or private, or even state or internationally sponsored. Only such independent agencies can guarantee that governments will not influence the results of their work.

1. For each governmental agency or political party, the level of antisemitism may be assessed by surveys among the staff or members and by the monitoring of antisemitic incidents.

2. The level of antisemitic prejudice in the population needs to ascertained by way of representative surveys. Such surveys should not only target whole populations but carefully distinguish between different parts of a population, such as Christians or Muslims, immigrants or locals, young or old. Although lacking these distinctions, a good practice example is the 2010/2011 representative survey of Austria by Maximilian Gottschlich and Oliver Gruber. ${ }^{8}$ Another subject of such surveys should include how Jews and Jewish institutions perceive and experience the antisemitism targeted against them. A good practice example is the 2012 survey "Discrimination and Hate Crime against Jews in EU Member States: Experiences and Perceptions of Antisemitism" conducted by the European Union Agency for Fundamental Rights (FRA). ${ }^{9}$

3. While representative surveys are an important indicator, their results need to be complemented by the monitoring of antisemitic incidents to assess both the theoretical presence of antisemitism and its concrete manifestations. The latter range from violence against persons to graffiti, threats, and the desecration of cemeteries in the real world and antisemitism present in the virtual world (see recommendations regarding the Internet). Monitoring should

8 Cf. M. Gottschlich and O. Gruber, Waldheims Erbe: Antisemitische Einstellungen der österreichischen Bevölkerung: Ergebnisse einer Repräsentativbefragung 2010/2011 (Wien: Institut für Publizistik und Kommunikationswissenschaft Universität Wien, 2011).

9 Cf. FRA - European Union Agency for Fundamental Rights, Discrimination and Hate Crime against Jews in EU Member States: Experiences and Perceptions of Antisemitism (Luxembourg: Publications Office of the European Union, 2014), http://fra.europa.eu/sites/default/files/fra2013-discrimination-hate-crime-against-jews-eu-member-states-0_en.pdf. 
be done both by Jewish organizations as well as by officially appointed bodies, such as the Fundamental Rights Agency (FRA). Results of surveys may prove contradictory, even not correlating with the known facts, so that a new carefully chosen matrix is needed. As of now, there is no unified methodology to monitor antisemitism; each agency and community has its own standards, and a common methodology is sorely needed.

\section{To Summarize}

Fair, commonly agreed upon, and full monitoring is still far from being achieved. It is one of the tasks that governmental agencies should encourage independent bodies to carry out with generous governmental financing. Surveys and reports should cover the local and national scenes and examine the social sphere in every country and should extend to the world as a whole. An intergovernmental independent institution, that will monitor the situation worldwide, is highly recommended as well.

\subsection{Comprehending the Problem: Analyzing what Motivates Antisemitism and Antisemitic Discrimination in a Country, a Branch of Government, a Governmental Agency, or a Political Party}

All branches of government, as well as politicians, are confronted with all forms of antisemitism in society at large and with antisemitism inside governmental agencies and institutions. Governmental decision makers and influencers have to ask, therefore, what are the causes of antisemitism in the country they are governing as well as inside governmental institutions or political parties. For the former, the reader is referred to the recommendations addressed to religious and cultural institutions and organizations. In case of the latter, antisemitic convictions, discrimination, and acts can have different causes. For each of these individual entities, it needs to be determined what motivates antisemitism and what encourages the antisemitic attitudes of those who participate in it. 


\subsection{Awareness-raising: All Members of Political Entities Need to Be Sensitized towards the Antisemitism in their Organizations.}

Raising awareness of antisemitism within a whole population works differently form calling attention to it within a specific branch of government, a governmental agency, a political party, or among politicians. Awareness-raising for the antisemitism in the society of a country is addressed in detail in the recommendations to religious and cultural decision makers.

Since politicians and governments participate in the shaping of the public discourse and the national narrative, when they publicly reject antisemitism, they set a personal example, bring about a moral repudiation of the phenomenon, and create a positive atmosphere towards Jewish citizens. A strongly worded and clear-cut message by leaders to their audiences is of utmost importance in the struggle against antisemitism. Declarations, marching at the head of demonstrations, speeches and statements of support, such as those issued by Pope Francis, Angela Merkel, Antonio Guteres and Manuel Valls, are known examples of such conduct.

In addition to the seminars and training courses recommended to raise awareness among government employees, mechanisms of public pressure and lobbying are recommended to influence politicians and political parties. Jewish communities and representative organizations should advocate with decision makers and alert them regularly about the current level of antisemitic discrimination, violence and persecution in their countries, informing them about the success of their efforts to combat antisemitism, or lack thereof. The annual reports of the Kantor Center, mentioned above, provide the necessary data for this purpose.

It is crucial to advocate with politicians to raise their awareness of the threat of antisemitism worldwide. Where applicable, campaign donors should connect campaign contributions with warnings about rising antisemitism and calls to action. Furthermore, public pressure through the media could also help to direct the attention of politicians and political parties towards the growing antisemitism of our time.

To raise awareness of antisemitism with decision makers, influencers, or staff of a branch of government or a governmental agency, we recommend that all decision makers and employees participate in special training courses and seminars about both the history and culture of antisemitism and about the history, culture, and religious practices of Judaism. These training courses should enable decision makers and influencers to recognize all forms of antisemitism, in- 
cluding accidental and structural antisemitism, but also to develop more appreciation for cultural and religious needs of their Jewish employees and business partners.

Both politicians and governmental employees should be exposed as much as possible to living Judaism, both in their home countries and in Israel. Positive practical experiences with Jewish culture and religion are of key importance to sensitize anyone to Jew-hatred.

\subsection{Applying Recommendations}

In addition to our own recommendations to political decision makers and influencers, we would like to bring to their attention a host of conferences organized by political bodies to deal with antisemitism as a major problem, especially in democratic societies. Their participants gathered much relevant material, reached conclusions and decisions, and even issued declarations. We recommend that governments and intergovernmental agencies use the very valuable material that was collected in order to better implement measures against antisemitism. Examples of these conferences and gatherings include the OSCE conferences in Vienna (2003), in Berlin (2004 and 2014) and in Cordoba (2005); the Parliamentary Assembly of the Council of Europe in 2007 and 2016; the London and Ottawa inter-parliamentary conferences that resulted in protocols to combat antisemitism unanimously adopted by parliamentarians from 50 countries in Ottawa in 2010; and the five Global Forums in Jerusalem, organized by the Israeli Ministry of Foreign Affairs.

\section{Special Recommendations for Decision Makers and Influencers of the Legislature}

Since antiquity, antisemitic agitation resulted in discrimination, persecution, and murder of Jews. Examples include the pogrom of Alexandria in 38 C.E., the pogroms connected with the First Crusade, the pogrom of Granada, the pogroms that followed the bubonic plague, the Spanish Inquisition, the Farhud, and the Shoah. History leaves no doubt that antisemitism often leads to the most horrendous forms of violence. This mechanism should be taken as an indication that manifestations of antisemitism often lead to a clear violation of basic human rights, laws, and covenants that undergird the world's societies and became part of international law. These include Article 18 of the Universal Decla- 
ration of Human Rights (1948), Article 18 of the International Covenant on Civil and Political Rights (1966), the OSCE Berlin Declaration of 2004 and more.

Antisemitism should therefore be taken as an incitement to violence that often leads to a violation of human rights. Not only antisemitic violence but all expressions of antisemitism should be subject to legal measures, if and where such measures exist in the local judicial system. Where such legislation is not in possible, countries should expand their anti-discrimination legislation to include antisemitism as a specific form of discrimination.

Since victims of antisemitism are entitled to any form of protection a democratic government can give them, legislatures should create laws that are preventive and protective to avoid antisemitic discrimination, persecution and violence. Legislators should create a legal framework that supports the recommendations for a long-term strategy to eradicate antisemitism.

To some extent, the recommendations following represent a wish list of laws that responds to the need for protection of Jewish citizens and institutions as well as to the need to effectively eradicate antisemitism. Happily, some of these recommendations are already in place in some countries.

The fight against antisemitism should not depend on changing short-term political considerations and the shifting priorities of the electorate because only long-term strategies that will be effective over generations hold the promise of eradicating Jew-hatred.

Combating and eradicating antisemitism should be anchored in the constitutions of all countries as a constitutional purpose if political circumstances allow for this. In democracies, only constitutional legislation can force both legislators and governments to do things that may not be popular with the electorate.

Most UN member countries have enacted laws prohibiting crimes motivated by racist, religious and ethnic hatred ("hate crimes") and incitement to hatred ("hate speech"), but antisemitic motivation is not mentioned in most of them. It is most often considered to be subsumed within the categories of the general legislation against hate crimes and hate speech. The UN Vienna conference on human rights of June 1993 declared antisemitism to be a form of racism, hence, allegedly no need for a separate legal treatment of antisemitism exists. The resolution of the conference became an excuse to avoid dealing with antisemitism. Thus, the challenge consists of recovering the narrative of human rights when antisemitism has been displaced or superseded by racism, xenophobia, and other forms of hatred. Moreover, this phenomenon has left antisemitism as an exclusively Jewish cause, undermining its relationship to basic human 
rights. Human rights are marshalled to nurture antisemitic sentiment through demonization and delegitimization of Israel.

Governments should be aware of the fact that few national penal codes include a specific description or mention of antisemitism (among them Colombia, France, Mexico, the U.S. and Spain). Similarly, antisemitism is not mentioned in any legally-binding international or regional treaty or convention, only in nonbinding resolutions and declarations. ${ }^{10}$ This situation needs to be changed. At the same time, states must wisely employ soft law instruments that define or condemn antisemitism, such as the 2016 IHRA definition that has been adopted by many countries although its legal status is non-binding.

The second most important recommendation is therefore:

- The parliaments of all countries should adopt the IHRA Working Definition of Antisemitism to establish a universal standard of what constitutes antisemitism. This should ideally be done in such a way that it is enforceable or with a certain legal standing.

- Regarding the adoption of the WDA, it is necessary to treat each state differently, considering differences among legal systems and political cultures in different countries.

- Those parts of the WDA that still wait to be implemented in certain countries need to be identified in order to strengthen those aspects of the WDA that countries are more reluctant to apply.

- Guidelines should be drafted for each country to implement the WDA and to monitor its use in prosecution and law enforcement.

Given all of the above, we strongly recommend the enactment of specific legislation against antisemitism and Holocaust denial as defined by the IHRA working definitions of antisemitism and of Holocaust denial. In Europe, we recommend also bringing cases concerning Jewish matters to the Strasbourg-based European Court of Human Rights. Its judgments are binding and require governments to amend their legislation in human rights-related areas.

- A first step towards such legislation against antisemitism and Holocaust denial would be to raise the discussion about this much needed change in each country's parliament under anti-discrimination laws that serve as an umbrella.

10 For details, see T. Naamat, N. Osin and D. Porat, eds. Legislating for Equality: A Multinational Collection of Non-Discrimination Norms (3 vols., Leiden: Martinus Nijhoff Publishers, 20122016). Vol. 1 covers Europe, vol. 2 the Americas, and vol. 3 Africa. 
- We strongly recommend that individual legislatures enact laws against Holocaust denial. So far only 22 countries out of the 192 UN member states have done so. ${ }^{11}$

- Create legislation that demands regular assessments of the level of antisemitism in a country and the monitoring of antisemitic activities.

An especially sensitive and difficult topic is the question of antisemitism and freedom of speech. An urgent need exists to distinguish between freedom of speech and freedom to incite. Hateful language and incitement cannot be regarded as a legally protected form of speech. The issue is not just what someone says, writes or publishes, but how it is perceived and interpreted. Therefore, a legal strategy needs to focus on the intent of the person who expresses antisemitic stereotypes to mobilize masses or groups to commit violence. The legal challenge is to protect freedom of expression and prevent hate speech at the same time, specifically in the case of antisemitic speech hidden under acceptable expressions. The case of the semantic overlap between "Zionist" and "Jew" is an example, reflected in the contrasting jurisprudence in Europe regarding cases of antisemitism directed against "Jews" or "Zionists" and the variable judgment of the courts.

- Legislation should be created recognizing that in the long run antisemitism as a whole always results in violence against Jews. Antisemitism should therefore be taken as an incitement to violence that is not protected as freedom of speech. ${ }^{12}$

- Publications, carrying antisemitic material about which there is no dispute as to their destructive contents, such as Mein Kampf, Protocols of the Elders of Zion, the Nazi propaganda film The Eternal Jew, Sayyid Qutb's essay Our Struggle against the Jews, and outright Holocaust denying materials, should be banned by law, and punished by heavy fines. Only academic and national libraries should be allowed to hold copies of them. The access to such contents should be restricted to antisemitism researchers (including advanced students) and those civil servants, politicians, and journalists who need them for their work.

- Legislation should prohibit companies and individuals from marketing or selling antisemitic memorabilia and contents in any form.

11 T. Naamat and I. Deutch, Legislating against Antisemitism and Holocaust Denial: Fall 2013 (updated: Summer 2018; The Kantor Center for the Study of Contemporary European Jewry, 2013), 2-6.

12 Cf. European Court of Human Rights, "European Convention on Human Rights,” https:// www.echr.coe.int/Documents/Convention_ENG.pdf, 12. 
- Legislation should force companies to accept the responsibility for marketing antisemitic contents and prohibit companies from selling or trading them in any form.

- Legislation should allow judges to prohibit the operation of antisemitic organizations and political parties based on evidence presented in court proceedings.

- We recommend that each government install institutes for the study of antisemitism, and that these be mandated to create blacklists specifying to which content these suggested laws should apply.

As argued before, the Internet is "the primary multiplier and locus for the transmission of manifestations of antisemitism". ${ }^{13}$ A second multiplier transmitting manifestations of antisemitism are other media such as satellite TV. All existing legal means need to be used to respond to antisemitic agitation in the on- and offline media. If no such legal means exist, the necessary legislation must be created.

- Legally-binding agreements should be reached with the main media servers, such as Google, YouTube, Facebook, and Twitter, since they carry the platforms on which antisemitism has most flourished in recent years.

- Isolated cases of the propagation of antisemitic stereotypes should result in a fine.

- Media outlets that propagate antisemitic stereotypes or regularly generate antisemitism should be closed and prohibited.

- Legislation should order the removal of any kind of webpage with content identified as antisemitic.

- Legislation should prohibit social bots, fake accounts, etc. through which antisemitic hate speech is spread.

- Laws should be created that make all online platforms liable for any kind of hate speech that is expressed on them. In their function in the virtual world, they function like a publishing house, journal or TV channel; they are hence responsible for the hate that is spread through their platforms.

13 M. Schwarz-Friesel, Antisemitism 2.0 and the Cyberculture of Hate: Hostility towards Jews as a cultural constant and collective emotional value in the digital age (short version), published online in 2018 (https://www.linguistik.tu-berlin.de/fileadmin/fg72/Antisemitism_2.0_short_version_final2.pdf), 3. A more detailed German version of the results of the DLG-funded long-term study "Antisemitismus im www" ["Antisemitism in the World Wide Web"] can be found on the website of the Technische Universität Berlin (https://www.linguistik.tu-berlin.de/fil eadmin/fg72/Antisemitismus_2-0_Lang.pdf). 
- Each country should develop special legislation against cyber-antisemitism and antisemitic contents on the Internet if it has not done so already.

- Laws should be created that block the broadcasting of antisemitic TV and radio stations via satellite and other means.

Any proposed legislation must attempt to balance the interests of protecting free speech and, at the same time, protecting against the spread of antisemitic incitement.

For legislators, another important matter to consider is the legal protection of Jewish religious practices. If such laws do not yet exist, we recommend that legislators should create laws protecting not only all cultic and ritual practices of Judaism but also those of other minorities. Examples for such practices include

- Circumcision

- Ritual slaughter

- Observance of Jewish holidays

\section{Special Recommendations for the Judiciary}

The judiciary branch of government has two responsibilities in the fight against antisemitism. On the one hand, it should do everything in its power to assess and eradicate any form of accidental or explicit antisemitism in its own institutions. On the other hand, as part of its decision-making, it should use all legal means at its disposal to restrain antisemitism.

\subsection{Antisemitism in the Judiciary}

In addition to the policies recommended there for all employees of government, decision makers and influencers of the judiciary are advised to follow the policies below.

- Training workshops should be organized for judges and prosecutors. Several recent rulings by prosecutors and judges in European courts show a discernible lack of understanding of antisemitism in its modern and contemporary forms and lack of basic knowledge of the history of World War II and of the Holocaust. Examples include the municipal court of Wuppertal, Germany which denied that an arson attack on the local synagogue was antisemitic 
in character, as it was intended to "to direct attention to the Gaza-conflict."14 Therefore, it is necessary to organize workshops for judges and prosecutors based on the WDA in order to improve the understanding of its legal implications. In these seminars, the WDA could serve as a uniform template for the investigation and prosecution of hate crimes. Good practice examples are seminars that are being held in Austria since 2015 in the framework of the training department of the Austrian Federal Ministry for Constitutional Affairs, Reforms, Deregulation and Justice.

- Law students in countries where law schools do not include human rights law should be trained in international human rights law dimension of antisemitism. This training could be offered by special seminars and summer schools targeting the students in question.

- Decision makers of the judiciary need to carefully monitor decisions by judges and others for accidental and intentional antisemitism.

\subsection{The Fight against Antisemitism by Members of the Judiciary}

Judges, prosecutors, and lawyers are in a highly respected position in the society of many countries. All members of the judiciary, therefore, have a unique ability to condemn the discrimination and hate of antisemitism and should do so publicly. Members of the judiciary can and should also put every effort into improving the legal system of their countries regarding the fight against antisemitism. For both purposes we recommend the following policies:

- Refrain from giving legitimacy to antisemites by refusing to participate in or speak at their events.

- Decry disinformation, hate speech, and antisemitic rumors and propaganda such as the Protocols of the Elders of Zion.

- Based on your legal expertise, forcefully and publicly argue against any discrimination against Jews.

14 B. Schrep, “Sechs Brandsätze in der Nacht," Spiegel online, January 18, 2016, http://www. spiegel.de/panorama/justiz/brandanschlag-auf-synagoge-in-wuppertal-taeter-erneut-vor-ger icht-a-1072396.html [“Sie hätten mit ihrer Aktion nur auf den Gaza-Krieg hinweisen wollen.”]; S. Laurin, “Wuppertal und die Branstifter,” Jüdische Allgemeine, January 12, 2017, https://www. juedische-allgemeine.de/article/view/id/27477 [“Die Behauptung der drei Täter, sie hätten mit ihrem Angriff auf das Bethaus die Aufmerksamkeit auf den Gaza-Konflikt lenken wollen, wurde ihnen von den Gerichten geglaubt."]; S. Wildman, "German court rules that firebombing a synagogue is not anti-semitic," Vox, January 13, 2017, https://www.vox.com/world/2017/1/13/ 14268994/synagogue-wuppertal-anti-semitism-anti-zionism-anti-israel. 
- Strengthen coordinated offensives among different actors against international organizations and bodies for their unequal treatment of Israel.

\subsection{Other Recommendations for the Legal and NGO Community}

- Augment activism in international organizations against antisemitism and Israel's delegitimization through increased submissions by NGOs and research centers.

- Create a coalition of established NGOs (e.g., Human Rights First, Amnesty International, Human Rights Watch) for campaigning against hate speech and antisemitism.

- Create a database of episodes and cases, advocacy and litigation against antisemitism.

- The database should contain different episodes of antisemitism that have been litigated or have been object of legal advocacy campaigns.

- This database should be available to any organization or activist involved in the fight against antisemitism for sharing experiences and creating possibilities of global partnerships.

- Organize regional legal workshops for circulating best practices.

- Legal workshops are fundamental for sharing best practices in the formulation of arguments and the understanding of successful strategies for dealing with antisemitism.

- However, the predominance of common law practice makes it difficult for civil law lawyers and activists to translate these practices into their own legal systems. Therefore, regional workshops are deemed to be the most efficacious way to circulate best practices and stimulate strategic thought because lawyers work on similar legal frames.

- Encourage legal activism and advocacy against antisemitism on the domestic and international levels.

- Define potentially winning cases of antisemitic hate speech and pursue criminal prosecution.

- Engage non-Jewish lawyers in the battle against antisemitism as an ethical call for the battle for human rights.

- A good practice example for legal activism against antisemitism is the International Organization of Jewish Lawyers and Jurists (IJLJ) that has branches in many countries. The European branch has had since 2012 a "Task Force" to combat rising antisemitism through legal means. Its members emphasize the need to have experts come to 
court, to guide activists who represent cases in international fora, and supply relevant material.

- Either launch or join Lawfare-a legal struggle for Jewish rights. Jewish rights have to be treated and protected equally to those of any other citizen. The reason underlying and justifying this recommendation is the uniqueness of the Jewish people that cannot be defined as a nationality, nor as a religion nor as an ethnic entity, but rather as a particular combination of these components. Hence the unique nature of antisemitism, as a centuries-long combination of religious, racial, economic and politically-rooted hatred and the necessity to enact separate legislation to combat it.

- Prepare and publish a legal guideline online and in print instructing the general public how to deal with antisemitic incidents

- Frame antisemitism as not just a problem of hate speech but also freedom of religion in order to prosecute those violent episodes against Jewish religious sites or Jewish persons that are identifiable as Jews by their clothing, names, practices, and other characteristics.

- Bring Hamas, Hezbollah, and Iran to justice based on the 1948 Convention against Genocide as well as any other group advocating mass murder.

\section{Special Recommendations for Decision Makers and Influencers of the Executive}

Many governments have put significant efforts onto fighting antisemitism but without the successes they desired. There are several reasons for this gap between efforts of the executive and lack of success. The triangle made of the extreme left, extreme right and radical Islamists does not include the audiences that are influenced by the results of governmental efforts. Radicals and extremists might not even be aware of these efforts, and, if they are aware of them, will ignore them anyhow. Mostly, only those who are already convinced about the evil of antisemitism will be open for educational and legislative efforts to fight it. The reasons for the immunity of antisemites towards educational approaches to fight antisemitism have been discussed in detail previously. Antisemitism, though, is not the domain of the extremists only, but became, at least in some countries, part and parcel of mainstream society as well. Such antisemitism is, at least in part, a consequence of widespread disenchantment with local governments and policies. Antisemites of the non-radical brand are therefore also resilient to governmental efforts to fight antisemitism. It is of utmost importance that government officials and political leaders realize the extent of the gap between 
their well-intended efforts and the limited success these efforts have had with antisemites in all parts of modern societies.

This discrepancy between governmental efforts, both on the national and the international level, and the limited success in fighting antisemitism points to the need for a new approach to the fight against antisemitism, which we hope to provide at least in part in this catalogue.

As emphasized previously, the fight against antisemitism should be guided by three basic considerations, namely, the religious and cultural nature of antisemitism and the assertion that many manifestations of antisemitism are a human rights issue. Combating antisemitism to a great extant implies fighting for human rights, a concept that is easily understandable by a larger public. However, it will fall short of success if it is forgotten that all forms of antisemitism-even seemingly secular, racist antisemitism-are dualistic religious convictions that are anchored in the cultural memories of most societies of the world.

Governments can and should contribute in several areas to the fight against antisemitism. Their contribution should concern fiscal, domestic, and foreign policy.

\subsection{Fiscal Contributions to the Fight against Antisemitism}

It is often surprisingly difficult to get funds for projects fighting antisemitism. The common implicit expectation that Jewish donors or Jewish foundations should fund efforts to research and combat antisemitism is in itself part of structural antisemitism that should be addressed in political discourse. While donations of individuals and foundations should and will always be welcome in the fight against antisemitism, it is the duty and obligation of the general public as represented by their governments to fund the fight against a phenomenon that most often leads to basic violations of human rights. We recommend therefore, that each government should allocate each year at least in excess of 0.02 percent of the gross domestic product of its country to the fight against antisemitism.

Some of the projects that should be funded in this way include

- The security of Jewish communities and institutions.

- In regular intervals, representative surveys that assess the level of antisemitism in a country.

- The continuous monitoring of antisemitic incidents.

- National and international hotlines, through which victims of antisemitism can ask for help and where cases of antisemitic acts can be registered (see below).

- The detection and removal of antisemitic contents on the Internet. 
- Institutes for the critical study of antisemitism in each country.

- Programs that facilitate cultural and religious encounters between Jews and non-Jews both at home and in Israel.

- Efforts to make accurate information about Judaism and the history of antisemitism easily available both on- and offline.

- Cultural and other exchange programs with the State of Israel.

\subsection{Domestic Policy}

In the realm of domestic policy, members of the executive have a wide range of options to fight antisemitism. In addition to the previously discussed measures, members of the executive could and should honor the victims of antisemitic persecution with special memorial days.

- In November 2005, the UN declared an International Holocaust Memorial Day, (IHMD) to be observed by ceremonies, educational programs, public gatherings, and governmental raising of awareness. Each UN member state was asked to adopt such plans, and a new department was set up, a UN Outreach Program, to help countries implement the UN decision. In 2017, 110 countries mentioned the IHMD, and leaders in most of them spoke about it. The Holocaust, being the most extreme manifestation of antisemitism, provides leaders with an opportunity to emphasize that World War II was a worldwide catastrophe-some 55 million lost their lives and a multitude of countries were physically devastated. The lesson is clear: What begins with antisemitism and persecution of the Jews, never ends with them.

- In addition to a Holocaust Memorial Day, each country should install local memorial days honoring the victims of local pogroms. A possible example could be an Austrian memorial day for the Vienna Gesara on March $12^{\text {th }}$ commemorating March $12^{\text {th }}, 1421$, when Duke Albrecht of Austria had two-hundred twelve Jews summarily executed because of their "wickedness."15 Another possible example could be July $4^{\text {th }}$ as a day to commemorate the pogrom in Kielce, Poland in 1946 when a blood libel incited the murder of fourty Jews in the Polish town of Kielce with a further eighty Jews being (severely) wounded.

15 The pogrom began on May 23, 1421, when Duke Albrecht had all Austrian Jews incarcerated and had most of them evicted from Austria one month later. 
Central to the well-being of all Jewish inhabitants of a country are measures to restrain antisemitism locally and to protect its victims. The protection and security of Jewish communities is extensively addressed by a catalogue of measures of the OSCE's Office for Democratic Institutions and Human Rights (ODIHR). ${ }^{16}$ Beyond the realm of protection, members of the executive can and should do more that contributes to restraining the influence and power of antisemites to the lowest conceivable level and to support their Jewish populations and institutions as much as possible. For this purpose the following policies are recommended: - All antisemitic organizations and political parties should be prohibited if the legislation of a country allows for that, and, if not, laws that provide the executive and the judiciary with that power should be enacted.

- Governments should take into consideration resolutions formerly adopted by other governments and parliaments regarding the combat against antisemitism. For instance, in March 2015 the Canadian parliament unanimously condemned the alarming global escalation of antisemitism and called on the Canadian government to make the combating of antisemitism a domestic and foreign policy priority. ${ }^{17}$ The French government decided in 2017 to finance more than 600 projects, both locally and nationally, under the umbrella of a new inter-ministerial program to fight racism and antisemitism, a program to be enlarged in the years 2018-2020 to become a national mobilization against hate and to reaffirm the values of the French Republic. ${ }^{18}$

- Each parliament should establish a working group to combat antisemitism. The independent scholars' committee established by the Bundestag in 2014 that handed in its extensive report in April 2017 is such an example. ${ }^{19}$ Each such working group should include Jewish experts as members.

16 Organization for Security and Co-operation in Europe, Understanding Anti-Semitic Hate Crimes and Addressing the Security Needs of Jewish Communities: A Practical Guide, May 15, 2017, https://www.osce.org/odihr/317191?download=true.

17 Cf. Jewish Telegraphic Agency, "Parliament unanimously condemns rise of anti-Semitism," The Canadian Jewish News, February 26, 2015, http://www.cjnews.com/news/canada/parlia ment-unanimously-condemns-rise-anti-semitism.

18 Cf. "Bilan 2017 des actes racistes, antisémites, antimusulmans et antichrétiens," communicated by Gérard Collomb, ministre d'Etat, Minister of the Interior on January 31, 2018, https:// www.interieur.gouv.fr/Actualites/L-actu-du-Ministere/Bilan-2017-des-actes-racistes-antisemitesantimusulmans-et-antichretiens.

19 Cf. Unabhängiger Expertenkreis Antisemitismus, "Bericht des Unabhängigen Expertenkreises Antisemitismus,” April 7, 2017, https://www.bmi.bund.de/SharedDocs/downloads/DE/pub likationen/themen/gesellschaft-integration/expertenbericht-antisemitismus-in-deutschland.pdf. 
- Each government should appoint a special envoy on antisemitism. This commissioner should serve as a point of contact for the Jewish communities, and as an interlocutor between them and the federal, state and local organs. A good practice example is the "European Parliament resolution on combating anti-Semitism" of June $1^{\text {st }}$, 2017. The resolution not only welcomes "the appointment of the Commission Coordinator on Combating Anti-Semitism," currently Katharina von Schnurbein, but "calls on the Member States to appoint national coordinators on combating anti-Semitism."20 In Germany, Dr. Felix Klein was appointed to such a position in 2018, and Bulgaria appointed Deputy Foreign Minister Georg Georgiev the national coordinator for the fight against antisemitism in 2017. With regard to an envoy on antisemitism, the current administration in the USA did not nominate a candidate for this position for a long time. A positive signal was sent, though, by the U.S. House of Representatives who voted to have the position renewed and promoted to an ambassadorial degree.

- With the office of each national coordinator on combating antisemitism, a national hotline should be created to report antisemitic discrimination and to offer victims of antisemitism an opportunity to ask for help. In case countries refuse to install such a hotline, it should be provided by an international political organization such as the European Union.

- Officials who express antisemitic opinions publicly should be named and shamed in public and forced to resign. If they refuse to resign, they should be dismissed. Decisions about such dismissals should be made by committees that would have to investigate each case, a significant part of whose members should consist of outside expertise.

- Abusive language of members of the executive and other decision makers and influencers should be denounced unequivocally by any country's leaders.

- Advocate for objectivity and journalistic standards in news media, stressing a commitment to the dignity and safety of the Jewish people, and the Jewish state's right to exist.

- In cases of clear-cut antisemitic agitation, members of the executive should do their utmost to abide by the legislation we recommend above, i.e., to prohibit such publications on- and offline.

20 European Parliament / Legislative Observatory, "European Parliament Resolution on Combating anti-Semitism,” June 1, 2017, http://www.europarl.europa.eu/sides/getDoc.do?pu bRef=-//EP//NONSGML+TA+P8-TA-2017- 0243+0+DOC+PDF+VO//EN. 
Another area where members of the executive could help is to facilitate intercultural and interreligious encounters and to initiate targeted education of minorities prone to antisemitism. We therefore recommend that members of the executive:

- Promote intercultural and interreligious encounters and dialogues of Muslim organizations and institutions, such as mosques, with both Jewish institutions and those institutions that support education against antisemitism.

- Support the dialogue work of many imams in the fight against antisemitism that includes their experiences in ongoing work against antisemitism in other Muslim communities.

- Facilitate personal and group contacts, such as Muslim-Jewish business enterprises, schools, and sports leagues, in order to give the "other" a personal face that minimizes group stereotypes.

- Develop preventive measures against religious extremism, particularly against Salafist radicalization in schools, mosque communities and youth welfare programs.

- Investigate the possible connection between immigration and antisemitism, and between immigration and terror. Given the likelihood of such a connection, as a first step seminars and courses for newcomers about the customs and traditions and dos and don'ts of their host country seem advisable. Such seminars and courses should include education about Judaism, its traditions and history, especially the local one, and about other minorities. A good practice example are seminars developed in Norway. ${ }^{21}$

- Much of what is said above with regard to Muslim terrorist antisemitism applies mutatis mutandis also to violent Christian antisemitic groups such as chapters of the Ku Klax Klan or the Aryan Nations/Church of Jesus ChristChristian.

- Empower and protect Muslims who state that extremist views and hatred of Jews are a distortion of true Islam. Such moderates must be empowered and supported because they are often in personal danger for advocating their views.

- Impress on Muslim leadership that governmental bodies that are vigilant against antisemitism and that promote education to that end are the insurance of human rights for all groups, including the human rights of Muslims.

21 The seminars are called "lov om introduksjonsordning og norskopplaering for nyankomne innvandrere" in Norwegian. Their commonly used short title is "introduksjonsloven" meaning "Introduction to Law." 
- Work in parallel with other minorities to fight antisemitism and other forms of prejudice and discrimination. In this way, the false impression of an exclusive concern for Jewish interests can be sidestepped, thus avoiding more resentment against Jews. What is needed is to promote the principle and strategy of intersectionality-to make common cause with other victims of racism and discrimination. Along that line, governments should encourage the cooperation between Jewish communities, civil society bodies, and NGOs, that are taking care of other minorities.

- Fund organizations that work for the integration of migrants and refugees based on the promotion of democratic values and immunization against antisemitism-and not according to ethno-religious credentials.

- Stop the funding of organizations that promote antisemitism, anti-Zionism, and terror and to bring such organizations to court. This same funding should be used for the work of organizations that try to integrate immigrants, by instilling in them democratic and pluralist values.

Many members of the executive have an elevated standing and are thus able to influence the public debate significantly.

We would like to bring the attention of politicians, though, to a special problem influencing the public debate, i.e., that antisemitism is moving into the mainstream of society and is not only the domain of the extreme fringes. It is common that antisemitic ideas in this way become part of an accepted public discourse. This situation leads, in turn, to a denial of antisemitism, a recent and new phenomenon now common in mainstream society, political parties, amongst intellectuals, and in academia. Mainstream antisemitism and denial of antisemitism are often hidden behind philo-semitic self-representations or behind alleged fair criticism of Israel. Opinion leaders and other intellectuals refuse to be labeled as antisemites or the authors of antisemitic texts by fostering an image of objective observers. It seems that opinions voiced today by the leftliberal elite or by right-wing elites in the U.S. are socially better accepted, and they are reaching a status of being permissible in mainstream societies, especially when clothed in implicit expressions and academic jargon.

\subsection{Foreign and International Policy}

The arena of foreign and international policy is key to the solution of many problems created by antisemitism. Antisemites organize and act today on an international scale. Only when politicians and other members of the executive coordinate their efforts on such an international scale as well can the restraint of 
antisemitism be successful. On a European level, the "European Parliament Resolution of 1 June 2017 on Combating Antisemitism" is crucial in this context. ${ }^{22}$ It is the first resolution by the European Parliament solely dedicated to the fight against antisemitism. The resolution formulates crucial recommendations for the Member States of the European Union to implement in order to fight antisemitism more effectively and to guarantee the security of Jewish communities in the European Union. On a trans-European level, the policy recommendations in this resolution resonate beyond the Member States of the European Union. They are also valuable for states seeking access to the EU, as well as countries who are part of the European Neighbourhood Policy. Beyond that, the European parliament resolution on combating antisemitism can also serve as a best practice example for countries elsewhere that are committed to strengthening the fight against antisemitism.

- Like national parliaments, we recommend the establishment of international working groups of members of parliaments as well. A good and rather successful practice example is the European Parliament Working Group on Antisemitism (EP-WGAS), which brings together Members of the European Parliament (EP) at a cross-party level to improve the way in which the EU combats Antisemitism, and for which the European Jewish Congress acts as secretariat and member of its advisory board. EP-WGAS is recognized as the primary vehicle used by the EP's Anti-Racism and Diversity Intergroup (ARDI) to deal with antisemitism in the European Parliament and nominates its Chair to the bureau of ARDI. Acting as initiator and advisor to the political groups in the European Parliament, EP-WGAS was instrumental in the adoption of the European Parliament Resolution on 1 June 2017 on combating antisemitism discussed above.

- For victims of antisemitism in countries that do not commit to the fight against antisemitism, an international hotline should be created by an international political organization.

- With regard to countries that are not committed to the fight against antisemitism, depending on the situation, international agencies and NGOs should intervene with due caution or should exert public pressure by way of "naming and shaming" to bring their governments to acknowledge the problem of antisemitism and its harmful effect on society as a whole. In this way, they

22 Cf. "European Parliament Resolution of 1 June 2017 on Combating Antisemitism,” Brussels, June 1, 2017, www.europarl.europa.eu/sides/getDoc.do?type=ta\&reference=p8-ta-2017-0243\&lan guage=EN\&ring=B8-2017- 0383 (accessed October 23, 2018). 
might understand that not only Jews, but all citizens and minorities of any country, benefit from the fight against antisemitism.

- The UN has become in recent years an arena for antisemitic and anti-Israelbiased debates and resolutions. Prof. Irwin Cotler, former Canadian Minster of Justice, recommends that national representatives not leave the UN or any other international body of similar nature, but stay to try to have an impact from within. Governments should let Jews take issues with such bodies and become plaintiffs so as not to leave international bodies to act alone. ${ }^{23}$

The question of Islamic antisemitism is a major policy issue. In the age of satellite TV and the Internet, the flow of hate messages and antisemitic agitation against the State of Israel from countries like Iran poisons the minds of Muslims and other people worldwide. Jew-hatred incessantly manipulates Muslims in Europe via social networks or state media in Turkish, Arabic or Farsi.

- Governments and intergovernmental organizations should condemn the blatant state sanctioned antisemitism that exists in a number of countries, such as Iran, and consider banning them in the international arena. The difficulty arises when it is perceived that such a ban might harm the economic interests of many countries for the sake of the well-being of one minority. For example, such countries would suffer if they refuse to make agreements with oil-abundant countries, and their support of the fight against antisemitism might affect other state needs It should be remembered, though, that genocidal antisemitism that calls publicly for the destruction of the Jewish state and for killing of Jews no matter where they are, starts with Jews but never ends with them. The other minorities attacked and murdered by Moslem Brothers or ISIS are one example.

- Encourage interfaith dialogue as well as Jewish-Arab-Muslim meetings for the discussion of issues of mutual interest, such as the meeting of Iraqi poets and writers with former Iraqi Jews in October 2017 in Berlin that discussed the Jewish cultural contribution in Iraq and the reasons for the demise of the community

- Politicians should raise the issue of antisemitism with representatives of Muslim states and begin to exert public pressure. Such foreign policy pressure should not be restricted to states like Iran but also include states like

23 Cf. "Report: UN Ignored Antisemitism for Decade," UN Watch, July 9, 2018, https://www. unwatch.org/report-un-ignored-antisemitism-decade/. 
Turkey. A good practice example is the 2014 meeting between former U.S. President Barack Obama and Turkey's president Recep Tayyip Erdogan. ${ }^{24}$

- All governments worldwide should denounce and punish state or non-state actors that allow Islamic antisemitism to spread by means of textbooks, mosques, and media.

- All governments should ban entities, such as radical Muslim organizations, that openly promote Jew-hatred, deny the Holocaust and/or call for violent acts. This includes a stop to the funding of organizations that promote antisemitism and anti-Zionism, religious fundamentalism, the inequality of women and hatred against minorities and that are still partners of Western state institutions today.

- All governments should investigate if their humanitarian contributions are being used by others to fund antisemitic actions or terrorism.

\subsection{Law Enforcement}

Guaranteeing the security of Jewish institutions and individuals is an urgent task that governmental decision makers should shoulder by taking immediate action. Indeed, a number of Western democracies put considerable effort into the physical protection of Jewish sites and persons, such France and the UK. But more states have to recognize the physical threat that Jewish communities are under both as Jews, at the hands of right-wing extremists and radical Muslims, and as citizens who are part of a society threatened by terrorism.

For the security of Jewish communities and institutions as well as the role of law enforcement in the fight against antisemitism, the OSCE Office for Democratic Institutions and Human Rights (ODIHR) has published an extensive catalogue that addresses the issue exhaustively and to which we would like to refer our readers. ${ }^{25}$ We will restrict our own discussion therefore to principal observations.

The security measures to be taken for the protection of Jewish communities and individuals require long-standing financial support that is a burden to governmental budgets. Nevertheless, such funding must be provided by governments as part of their obligation to provide security for all citizens and inhabi-

24 J. Jalil, “Obama Urges Turkey to Combat Anti-Semitism,” The Times of Israel, September 9, 2014, http://www.timesofisrael.com/obama-urges-turkey-to-combat-anti-semitism/?fb_com ment_id=640806102701780_641055739343483\#ffd87cf0eb873b8.

25 Organization for Security and Co-operation in Europe, Understanding Anti-Semitic Hate Crimes and Addressing the Security Needs of Jewish Communities: A Practical Guide, May 15, 2017, https://www.osce.org/odihr/317191?download=true. 
tants. Jewish communities should neither be expected nor required to pay for their own security needs. We urge the relevant officials to remember that these expenses are interwoven with the overall expense of security: more police on the streets and around communal sites and better intelligence shared by agencies help to keep public order and are a deterrent not only against terrorism targeting Jews but against all terrorism. We strongly recommend that protective measures be taken in cooperation with Jewish institutions and communities that must be especially attentive to young people because the very presence of army and police near and around Jewish installations might cause children anxiety. A good practice example includes the 10.000 soldiers allocated in 2017 by the French government to protect the Jewish sites. The president of the Conseil Représentatif des Institutions Juives de France (CRIF), at that time Roger Cukierman, stated, "We cannot ask for more." ${ }^{26}$ Despite this massive French protection effort, despite the allocated budgets, and despite educational programs, violent antisemitic incidents increased in France during the year 2017 as compared to 2016 (97 compared to 77) according to the French ministry of the interior. ${ }^{27}$

Though Jews are entitled to government protection as well as any other citizen, Jewish youngsters should be given the chance to take an active part in the protection of their own families and places for the sake of safeguarding their dignity.

Better protection will be achieved once the Jewish communities gain trust in the local authorities and are confident that these authorities are acting for their benefit. In this regard, the hotlines mentioned above are of utmost importance. They will enable victims to report immediately or even get immediate help. Very few such hotlines exist and many more are needed. Trust in the state organs will bring about not only the needed help but also better reporting and monitoring.

Similar to the training of judges and prosecutors requested above, training programs for police officers and other law enforcement personnel are needed. These training programs should be guided by the WDA as a uniform template for law enforcement authorities in the investigation and prosecution of hate crimes. In some countries the training of police officers making use of the

26 A. Borschel-Dan, "French Government Doing Utmost to Protect Jews, Says Leader," The Times of Israel, November 17, 2015, https://www.timesofisrael.com/french-government-doing-ut most-to-protect-jews-says-community-leader/.

27 For exact numbers of the 2017 report of the French Ministry of Interior, cf. "Bilan 2017 des actes racistes, antisémites, antimusulmans et antichrétiens," communicated by Gérard Collomb, ministre d'Etat, Minister of the Interior on January 31, 2018, https://www.interieur.gouv.fr/Ac tualites/L-actu-du-Ministere/Bilan-2017-des-actes-racistes-antisemites-antimusulmans-et-anti chretiens. 
WDA has begun years ago: ${ }^{28}$ EDPOL, the European Diversity in Policing, an initiative of European police agencies to train officers who will be posted in sensitive areas, is now replaced by the FRA, the Fundamental Rights Agency. EDPOL and FRA should refocus and expand their efforts to train police officers on how to deal with antisemitic incidents.

\section{Special Recommendations for Decision Makers in Political Parties and Influencers of the Political Discourse}

Political parties play a key role in many democracies. Accidental or explicit antisemitism in them are thus particularly dangerous and even more so political parties that are committed in their principals to antisemitism. The latter should be prohibited. We therefore recommend the following policies to political parties:

- Each political party should endorse and apply the Working Definition of Antisemitism (WDA).

- The constitution or bylaws of each political party should include a clause that antisemitism as defined by the WDA violates democratic principles, and many manifestations of antisemitism violate human rights. Cases of explicit antisemitism are therefore cause to reject new members or to expel existing members.

- A statement that antisemitism is an affront to human rights, clearly introduced into the constitution of each political party, will facilitate the resignation of members voicing antisemitism.

- Each political party should therefore encourage outside investigation into incidents of antisemitism among its members.

- Antisemitic activities of party members confirmed by such investigations should result in suspension or expulsion depending on if an antisemitic incident was explicit. Expulsion should be mandatory for all party members holding public office.

- Political parties should not hire antisemites.

- Political parties should not nominate antisemites for any public or party office.

28 One such training seminar took place, for example, in Dublin, in 2014. Ireland has been the most active country in this regard. 
- During electoral campaigns, candidates should be encouraged to sign a pledge committing them to fight antisemitism if elected.

- Party leaders should denounce all antisemitic utterances and publications of politicians, who wish to attract votes by using antisemitic propaganda. Politicians who use such propaganda should know that there is a price to be paid, by losing party, public, and governmental support.

\section{The BDS Movement}

A form of antisemitism particularly debated today is connected with what began as the Arab boycott and what is now known as the BDS (Boycott, Divestment and Sanctions) movement. This movement officially started in 2005 although the Arab boycott dates from the time of the founding of the State of Israel in 1948. It attempted to create a situation in which companies that sought to do business in the Arab world would have to forswear any business contacts with Israel. There was a time in the not-so-distant past when many companies actually succumbed to these threats. As of May 2018, a total of 25 states of the U.S. and the federal government have passed anti-BDS legislation, making compliance with the Arab boycott illegal..$^{29}$ In Canada, in 2016, a non-binding motion was passed in the Legislative Assembly of Ontario that "calls on the legislature to stand against any movement that promotes hate, prejudice and racism" and "reject the 'differential treatment' of Israel by the BDS movement." ${ }^{30}$ In France, hate speech laws have been applied to BDS activities. ${ }^{31}$ In Spain, twenty-seven out of

29 A list of all states including summaries of the anti-BDS legal statements can be found in the Jewish Virtual Library, “Anti-Semitism: State Anti-BDS Legislation,” accessed October 9, 2018, https://www.jewishvirtuallibrary.org/anti-bds-legislation.

30 "Press Release: CIJA Applauds Ontario Legislature Motion Rejecting BDS," Canadian Jewish Advocacy, December 1, 2016, https://cija.ca/press-release-cija-applauds-ontario-legislature-mo tion-rejecting-bds/. For the original text of the Standing Up Against Anti-Semitism in Ontario Act, cf. "Bill 202, Standing Up Against Anti-Semitism in Ontario Act, 2016," Legislative Assembly of Ontario, accessed October 9, 2018, https://www.ola.org/en/legislative-business/bills/parlia ment-41/session-1/bill-202.

31 France's Declaration of the Rights of Man and the Citizen of 1789 (Déclaration des droits de l'homme et du citoyen de 1789) includes the freedom of expression, the freedom of press was consolidated in 1881. However, this freedom does not encompass racism, antisemitism, racial hatred and justification of terrorism. In October 2015, the French Supreme Court (Cour de cassation) officially prohibited the "boycott call by movement associations or citizen to criticize the policy of a third State," considering it a violation to article 24, §8 of the French Press Law that prohibits provocation for discrimination or hatred. Following this legal decision, BDS activities have continuously been considered public offences according to the Cour de cassation statement of Oc- 
fourty-five municipalities cancelled their ban on Israel because, according to Spanish law, a municipality is not entitled to enact it. ${ }^{32}$

Making the boycott even more insidious, companies seeking to do business in the Arab world were sworn away from doing business with Jewish-identified companies, especially those that had contact with Israel. This tertiary boycott affected many businesses owned by Jews throughout the world. BDS harms the legitimate interests of the general public, businesses, and America's longstanding ally, Israel. BDS seeks to cripple brands affiliated with Israel or that are Israeli invented, yet Israel is at the forefront of technological and medical innovation. The BDS boycott list includes: Nestlé, Motorola, Hewlett-Packard, Starbucks, Coca Cola, Sodastream, Revlon, Victoria's Secret, and Proctor \& Gamble. Even Disney was boycotted because Disney World's Theme Park Epcot's exhibit acknowledged Jerusalem as Israel's capital. In addition, companies that have had factories in the West Bank have been forced to close their operations by BDS advocates, putting Palestinian workers, the very people they claim to champion, out of work.

On the whole, the movement has been less successful in the United States than in Europe, where a number of pension funds and private banks have divested from targeted companies. In the United States, several university student bodies have called on their schools to divest. Though to date none have done so, the movement has made Israel a polarizing issue on U.S. campuses. Several scholarly organizations and other academic bodies have committed themselves, though, to the BDS movement.

All in all, this economic boycott ceased to be very successful because companies found that doing business in Israel was much more worthwhile than restricting themselves to the Arab world with its less developed and less innovative economies. Gradually, companies made clear to Arab governments that they would cease upholding the boycott, and the Arab world seemed to accept this situation.

While BDS has succeeded to a very limited extent, perhaps more insidious than its actual economic effect is the fact that it has clearly moved beyond opposition to Israel's domestic and foreign policy.

tober 2015 and are thus punishable by law. Cf. "France outlaws Boycott, Divestment and Sanctions (BDS),” Conseil Représentatif des Institutions Juives de France, November 10, 2015, accessed October 9, 2018, http://www.crif.org/en/actualites/france-outlaws-boycott-divestmentand-sanctions-bds/57796.

32 Cf. Jewish Telegraphic Agency, "Spanish Municipality to Cancel Resolution Boycotting Israel,” The Times of Israel, August 25, 2016, https://www.timesofisrael.com/spanish-municipalitynixes-resolution-on-boycotting-israel/. 
Holding Israel to a double standard and neglecting gross human rights violations of other countries, particularly in the Middle East, to focus on Israelbashing are forms of antisemitism. As it developed, especially in the European environment, it has increasingly been closely linked with antisemitic tropes and with demands of Israel that clearly are unlike those demanded of any other nations in the world, an approach that usually indicates antisemitic prejudices. It is quite common to see protest signs, cartoons and other materials regarding BDS that are clearly based on and connected to antisemitic themes and symbols. While it is difficult to determine exactly the boundary between boycott as a means of political protest and as a manifestation of antisemitism, it is clear that the two have often merged as a major problem today. While there has been much argument about the question of whether BDS must be considered antisemitic, and, for that matter, what is the boundary between antisemitism and opposition to Israel, it is widely agreed that the antisemitism in this movement must be stamped out.

As argued above, BDS applies a double-standard to the State of Israel and its citizens. The BDS sponsorship of the delegitimization and demonization of Israel can lead to human rights issue.

Sanctions against Israel are counterproductive. Keeping abreast of the latest in technology from agricultural aids, to disaster relief, to medical devices, will reveal many inventions that originate in Israel. These important enterprises are having a positive global impact, especially in less-developed countries. The stifling of academic interchange and pressure on performers and entertainers to withdraw from Israeli tours is another manifestation of BDS. Given that BDS can lead to violations of human rights, anti-BDS legislation is a wise and constitutional alternative that should be adopted in Europe and elsewhere.

We therefore call on members of all branches of government and of all political parties as well as all other decision makers and influencers:

- To make BDS and other such boycotts illegal when and where they violate existing laws.

- To publically challenge organizations that refuse to do business with Israel or that will not deal with companies that trade with or have offices in Israel.

- To not subscribe to boycotting Israeli imports and to not refuse to buy products that are sold in Israel.

- To not allow your company, university, etc. to remove its investments in the Israeli economy and academia.

- $\quad$ To not subscribe to wholesale sanctions against Israel. 


\section{Antisemitism and the State of Israel}

Far be it for us to advise the government and administration of the State of Israel regarding the means to combat antisemitism. Yet it is clear that the hopes and illusions of the forerunners of Zionism and the dreamers about an establishment of a Jewish political entity did not materialize: From 1948 up to the Six Day War in 1967, the level of antisemitism decreased worldwide, but from the 1970's on, it came back in a number of forms-the rise of the extreme left coupled by Soviet interests in the Arab and Third Worlds targeting Israel as a colonial capitalist endeavor; the comeback of extreme right-wing movements that wish to whitewash the past; and radical Islamists, whose goal is to foster a Muslim antisemitic identity as a tool against Israel.

Today Israel is targeted from the three sides of this triangle, and the more it is recognized as a Jewish state, the more the image of the Jews, and their alleged characteristics, as individuals and as a collective, is being transferred to their state. Therefore, let us suggest a few modest recommendations, along the ones already outlined in this catalogue:

- To convene the Global Forums organized by the Ministry of Foreign Affairs in regular intervals, and to continue in the interim the initiatives raised in the forums.

- To renew a forum established by now supreme-court judge Elyakim Rubinstein when he was Secretary of the government, in which representatives of all bodies that deal with antisemitism will participate, again-on a regular basis.

- To enhance and strengthen the cooperation that already exists between the two departments for the struggle against antisemitism, one in the Ministry of Foreign Affairs and the other one in the Ministry of Diaspora Affairs.

- To go on acknowledging the efforts of academic institutes to conduct independent research, both for purely academic purposes, as well as for the needs of the state organs to be updated and advised.

- To offer as many opportunities as possible for visits to Israel by decision makers, influencers and youth groups from the Western and Muslim worlds. These visits should be coupled with seminars, lectures and encounters, in which the history of the country and the people, the customs and traditions of Judaism and modern Israel, will be taught to as many visitors as possible.

- To enhance contacts with world leaders, with opinion shapers in all fields, and with media channels, so as to put forwards the country's responses for accusations, and try to reverse negative images by offering positive ones instead. 
- To cooperate as closely as possible with the Jewish communities abroad, their leaders and organs, and to remember that Jews in the diaspora are the first ones to face the results of the Middle Eastern conflicts and of Israeli policies.

- To be active in international fora and not to leave them or ban them, even if hostility is the order of their day, but to rather try to change their agenda.

- To train as many students, faculty, and company personnel as possible, who go abroad for short stays, to spread the word, equipped with the proper materials.

- To avoid a xenophobic approach of Jews and Israelis toward Arabs and Muslims as well as Christians. Israel can serve as a positive model for inter-confessional relations.

\section{To Summarize}

Antisemitism most often provokes human rights violations. Therefore, all governments, governmental agencies, and political parties have a special responsibility to do their utmost to repress and eradicate antisemitism.

Because of the involvements, combating and eradicating antisemitism should be anchored in the legislation an/or constitutions of all countries, and the Working Definition of Antisemitism should be accepted by all branches of government, by all international organizations, by all political parties, and by all other political decision makers.

Each government should allocate each year at least in excess of 0.02 percent of the gross domestic product of its country to the fight against antisemitism. Governments should undertake both nationally and internationally regular assessments of the level of antisemitism both by representative surveys and by monitoring antisemitic incidents on- and offline.

All branches of government should cooperate in suppressing antisemitic publications and contents on- and offline, in blocking antisemites from holding positions of political or governmental influence and in dissolving and prohibiting all antisemitic organizations and parties. Governments should appoint special envoys on antisemitism and install hotlines to which victims of antisemitism can turn for help. Governments and political parties should sensitize all their members and employees to antisemitism by way of special seminars. All members of government and all politicians should use their influence to speak out against antisemitism and "name and shame" everyone who holds antisemitic views or commits acts of antisemitism. 
